\title{
UTERATURE-BASED EXTENSIVE READING ACCOMPANIED BY READING LOGS: A CASE FOR DEVELOPING CRITICAL THINKING SKILLS OF ENGLISH UTERATURE STUDENTS
}

\author{
Fatemeh Khonamri \\ Mahmoud Azizi \\ Masoumeh Farzanegan \\ University of Mazandaran
}

fkhonamri@umz.ac.ir, mazizijam@umz.ac.ir

First draft received: 29 February 2016

Final proof received: 24 July 2016

\begin{tabular}{|l} 
Abstract \\
This study attempted to examine the effects of an ER program accompanied by reading logs on the \\
degree of critical thinking skills of sophomore English literature students at the University of \\
Mazandaran. Two groups of English Literature majors formed the two experimental groups of the study \\
in which only the former kept guided reading logs, while the latter group only read extensively. \\
Participants were also divided by their proficiency in reading into two groups of high and low achievers \\
to compare the differences, if any, in the critical thinking skills observed. The results of the Independent \\
t-test indicated no significant difference between the groups regarding their critical thinking ability (sig= \\
.900). Thus, it was concluded that although both groups showed a little progress after the treatment, the \\
difference was not statistically significant whereupon to conclude that reading logs may not drastically \\
affect learners' critical thinking development. \\
Keywords: Extensive reading, reading logs, critical thinking, literature-based reading \\
To cite this paper (in APA style): \\
Khonamri, F. \& Farzanegan, M. (2016). Literature-based extensive reading accompanied by reading logs: \\
A case for developing critical thinking skills of English literature students. International Journal of \\
Education, $9(1), 58-67$. doi: dx.doi.org/10.17509/ije.v9i1.3719 \\
\hline \hline
\end{tabular}

\section{INTRODUCTION}

As the awareness of the role of foreign languages on other types of learning increases, the importance of providing language instruction that meets the demands of the world where we live increases as well. The world of "quick-thinking", "risk-taking", "onthe-spot-decision-making" and "critical thinking" which emphasizes a higher order of thinking skills as the ultimate objectives of instruction needs to be considered by educators (Ellison, 2010, p. 1). However, most of the instruction of either languages or other disciplines in our educational environment tends to focus on fact transfer and information recall which belongs to the lowest level of Bloom's taxonomy of educational objectives (Nickerson, 1987; Kennedy, 1991; Paul, 1993). Unfortunately, the situation in Iran is not different. Language teachers, based on traditional teaching approaches, do not usually provide learners with the opportunity to express their critical ideas. The learners are not led to believe that they have every right to accept or reject the ideas presented by the others and do not take them for granted. Therefore, the system is mostly the traditional "banking system" in which teachers and books are the sources of knowledge and students should simply be able to regurgitate what is fed to them. Consequently, students do not learn to use their thinking skills much (Barjesteh \& Vaseghi, 2012). For example, in a traditional English reading instruction, like most of reading classes in our country, students are mainly taught to improve their language skills, first to expand their vocabularies and then to improve reading comprehension ability. What is expected of these learners is to obtain information or knowledge from the text and accept the ideas or viewpoints presented by the author. Most of the reading articles worked in language classrooms are humorous stories, scientific articles, and so on, but the number of argumentative articles with strict logic is few (Wen et Liu, 2006, cited in Xu, 2011). The reading exercises typically include multiple-choice questions to test students' comprehension. Xu (2011) believed that traditional lecturing and classroom activities are not very helpful in fostering students' critical thinking.

According to Fascion (1999, cited in Forood \& Farahani, 2013, p. 5), inference, analysis and synthesis which are the mental skills that "form the core of critical thinking skills" are becoming of utmost importance in reading comprehension activities, the very fact that according to Grabe (1991) has increased the potentiality of reading instruction to enhance critical thinking skills in language classrooms. However, other less direct means of nurturing such skills are also finding their ways into the language instruction as well. Today, according to Khatib, Rezaei and Derakhshan (2011), literaturebased reading is unanimously agreed upon as one of the main sources of critical thinking enhancement in language classes. By combining literature-based extensive reading (ER) and writing, language learners are required to write summaries or commentaries, 
read journals, and create similar stories or compose an argumentative text of their own. This could train students' higher level of thinking skills, synthesis, and application (Xu, 2011). Regarding the interconnectivity of language skills, Brown (2001, as cited in $\mathrm{Xu}, 2011)$ contended that "reading ability will best be developed in association with other skills, especially the reading-writing connection" (p. 140). Therefore, by considering the potentiality of reading accompanied by writing activities to enhance critical thinking skills, a new way to teach English reading with the aim of engaging learners actively and focusing on developing students' critical thinking through literature works needs to be proposed by language instructors. According to Paul (1995), language learners should be trained to be critical readers who can "question, organize, interpret, synthesize, and digest what they read" (as cited in $\mathrm{Xu}, 2011$, p. 491). Moreover, empirical tests of the effects of writing on thinking and learning from texts have proved that writing in conjunction with reading results in learning or better understanding (Applebee, 1984). In addition, a group of related studies suggests that reading in combination with extended forms of writing (e.g., analytical or personal essays) leads to a more thorough understanding of topics in both literature and the social sciences (Langer \& Applebee, 1986; Tierney, Soter, O'Flahavan, \& McGinley, in press, 1989).

Thus, to explore the issue further, the present study attempted to explore the possibility of improving the critical thinking skills of literature students through an indirect means of engagement with thinking about the text through writing a reading log. It goes without saying that one of the purposes of using reading logs to accompany literature-based extensive reading was to provide the learners with guided assistance in a step by step manner. Therefore, the following research questions were posed and investigated in this study: (1) Does literature-based extensive reading and log writing help undergraduate students in developing their critical thinking skills? And If yes, what critical thinking skill is mostly used by undergraduate learners in their reading logs?

\section{Critical Thinking Definitions}

"Good thinking" and "thinking well" are commonly used terms bound up with what is called "critical thinking" in the research of literature (Pithers \& Soden, 2000, p.237). Critical thinking involves both cognitive skills and dispositions (Facione, 1990, cited in Lai, 2011). These skills include the component skills of analyzing arguments, making inferences using inductive or deductive reasoning, judging or evaluating, and making decisions or solving problems. Background knowledge is a necessary but not sufficient element for enabling critical thought within a given subject. Critical thinking dispositions, which can be seen as attitudes or habits of mind, include open- and fair-mindedness, inquisitiveness, flexibility, a tendency to seek reason, a desire to be well-informed, and a respect for and willingness to entertain diverse viewpoints (Huitt, 1998).

Critical thinking has been defined and interpreted differently by different scholars and thinkers. Like many other concepts and constructs, there is little consensus on its definition. Paul (1988) defined critical thinking as the ability to reach sound conclusions based on observation and information.
According to Norris (1985), critical thinking skills help students apply what they already know to evaluate their own thinking. Critical thinking in the field of education has also attracted discussions. Bloom' taxonomy of educational objectives (1956) is one of the most widely used sources in the field of education when it comes to teaching and assessing higherorder thinking skills. This taxonomy consists of three domains: cognitive, affective and psychomotor, each involving several categories. There are six categories in the cognitive domain, starting from the simplest behavior towards the most complex one. The simplest objectives must be normally mastered prior to the more complex ones. These categories are: 1) Recalling information, 2) Comprehension, 3) Application, 4) Analysis, 5) Synthesis, and 6) Evaluation. According to this model, higher levels of educational objectives are achieved when learners reach the levels of Synthesis and Evaluation. Therefore, they are able to appraise, compare, conclude, contrast, critique, defend, justify, and think critically (Kennedy, 1991).

This paper has no intention to adhere to a single definition of critical thinking. Instead, the idea of critical thinking as a complex concept would be better investigated by considering a variety of dimensions. Therefore, as the main focus of this paper is to introduce tactics and strategies to be used in Iranian reading classes to promote critical thinking through combining ER with log writing, those aspects of critical thinking which can be fostered through combining reading and writing, such as synthesis, analysis, and evaluation, would be emphasized.

\section{Critical Thinking in the Field of Education}

While contemporary education curriculum is a highly contested arena, there seems to be a unanimous agreement that it should help students think well and think for themselves (Pithers \& Soden, 2000). According to Garrison (1991), teaching critical thinking is an identifying characteristic and central function in the field of adult education. There are scholars who have argued the validity of teaching critical thinking skills in an ESL/EFL context (Atkinson, 1997; Day, 2003; Kubota, 1999). Taglieber (2003) contended that many teachers believe students will develop critical thinking and critical reading skills automatically as they age and gain more experiences in different fields of knowledge through reading in school, and through life itself, but various scholars in the field have challenged this view. Nosich (1992), for example, believed that critical thinking must and can be taught to students, and that it is, in fact, the responsibility of the teachers to develop students who will have the ability to read and think critically. This view has also been supported by some other authorities in the field such as Chaffee (1992), Nickerson (1989), and Wilson (1988). On the whole, there are two approaches to the idea of teaching critical thinking, the process approach and the content approach (Fahim \& Bagheri, 2012). Process approach is in favor of dealing with critical thinking as a separate and independent course, while content approach votes for teaching it within established courses. Those who support the process view (e.g., Lipman, 1988) believed critical thinking is an enabling discipline and deserves separate instruction. Advocates of the content approach, on the other hand, maintained that teaching such 
cognitive skills is more effective, provided the instruction is given in context (Ashton, 1988). Some scholars such as Presseisen (1988) supported a unified view and thought critical thinking can be taught more effectively if the two approaches are combined.

According to Chaffee (1992), learners cannot rise any higher than the people who are to teach and inspire them. In order for students to develop their critical and creative thinking abilities, they must be taught by faculty who are themselves critical and creative thinkers, who express these qualities in every stage of their instruction. He proposed an organic model of professional growth for instructors to pursue, in which faculty members actively participate in the process of their own teaching, the very model that would also suit EFL learning contexts.

\section{Literature-Based Reading and Developing Critical Thinking Skills}

Various scholars have made somehow similar justifications to rationalize the integration of language and literature in EFL classrooms. For example, as Ellison (2010, p.22) put it, there are five pedagogic reasons why literature should be used in the foreign language classrooms: 1) attitudinal, 2) linguistic, 3) cultural and intercultural, 4) Social and moral, and 5) cognitive and creative. Ghosn (2002) also mentioned "four good reasons" to integrate literature and language, namely raising motivation, language learning, academic literacy, and literature as a change agent (p. 174). In a similar vein, Van (2009) believed studying literature in the EFL classroom is advantageous for a number of reasons: It provides meaningful contexts; it involves a profound range of vocabulary, dialogues and prose; it appeals to imagination and enhances creativity; it develops cultural awareness; it encourages critical thinking; and, it is in line with CLT (Communicative Language Teaching) principles (cited in Bagherkazemi \& Alemi, 2010, p.3).

By reviewing the literature, one can find out that the most unanimous justification made by the scholars and instructors on the integration of literature in language teaching is the power of literature to enhance the power of thinking among learners. Literature provides a rich source of imaginative input that helps students develop their innovative power. As Shelley (1989, cited in Khatib \& Shakouri, 2013) put it, literature is the expression of imagination. Cownway (1996, in Khatib \& Shakouri, 2013) also asserted imagination forms bridges between existence and perception, between perception and expression. Since the nature of literature in general is to engage readers intellectually in the literary works, it is thought that literary novels and stories can provide students with some opportunities to employ such critical thinking skills as analyzing, judging, synthesizing, evaluating, and thinking logically. On the other hand, it is argued that "literature should be excluded from the ESL curriculum because of its lexical structural complexity, non-normative standards of language and remote cultural perspectives" (Topping, 1968, cited in Khatib \& Mehrgan, 2012, p. 169). But, according to Khatib and Mehrgan (2012), these special characteristics of literature could be of great help to students in that they may develop intellectually. Reading literary short stories would help students take a critical look at all aspects of language learning, thus developing their critical thinking (Amer, 2003; Bagherkazemi \& Alemi, 2010; Elliot, 1990; Floris, 2005; Ghosn, 2002; Khatib et al. 2011).

Literature suggests several approaches to teach literary texts in an EFL classroom. Amer (2003), for example, presented two pedagogically effective approaches to treat literary material: The "Story Grammar Approach" (SGA) and the "Reader Response Approach" (RRA). The (SGA) approach puts an emphasis on the idea that there is an interaction between the reader and the text. In other words, the reader becomes aware of the text structure by interacting with the text and relating ideas from the text to prior experiences to construct meaning. A part of this process requires the reader to understand how the author organizes his ideas, i.e. the text structure. "Text structure" is a term used to describe "the various patterns of how concepts within text are related" (Amer, 2003, p. 63).

The (RRA) approach is based on a premise of teaching literature for literature's sake, not for language learning and development purposes. According to Ali (1994), this approach is rooted in constructivism, where each individual constructs his/her own version of reality when encountered the text. In other words, each individual responds differently to a single text. Therefore, learners come up with multiple interpretations rather than a single correct interpretation of a text (Amer, 2003). As cited in Amer (2003), there are different ways to implement RRA in literature classes including: 1) Reading Logs; 2) Response Journals; 3) Writing Prompts; and 4) Critical Questioning and Writing.

By reviewing literature, it is easily inferred that integrating literary material with language teaching provides a motivating prompt for language learning and teaching due to its great features not readily found in any other texts (Khatib et al., 2011). As Ghosn (2002) asserted, language skills, intercultural awareness, and thinking skills are of high priorities in the increasingly global world that could be effectively addressed in an EFL class through the medium of literature.

\section{ER and Log Writing and Developing Critical Thinking Skills}

Reading is often promoted as a good way to improve learners' second language proficiency, especially in input-poor environments. "But if some reading is useful, then perhaps extensive reading is even better" (Day \& Bamford, 1998; Horst, 2005, as cited in AlHomoud \& Schmitt, 2009, p. 384). Extensive reading motivates learners to read a large number of materials on a wide range of topics since the learners themselves select the reading material based on its relevance to their interests, knowledge, and experience. Students read texts that match their language level, and they choose the time and place to read (Day \& Bamford, 2002). However, it is important for the teachers to make the objectives of the ER program clear to the learners and monitor them properly during the program, as according to Campbell (1989), Davis (1995), and Day and Bamford (1997), one of the characteristics of a successful reading program is students' involvement with post-reading activities (cited in Aliponga, 2013, p.73). One of the post-reading activities that engage readers actively in their own learning process is keeping reading journals. Students use their reading 
logs to regularly take note of various aspects of language and content related to their reading. Completing the entries in their reading logs at pre-, during-, and post-reading intervals helps students learn strategies to enhance reading comprehension, activate new vocabulary, and develop writing skills. The logs are an opportunity for students to express their attitudes towards a text, reflect on their discoveries, and make connections between their current and already held knowledge (Lyutaya, 2011). According to Dorn and Soffos (2005), writing helps students integrate different sources of information and organize their thoughts; as a result, their thinking becomes much more fluid, flexible, and tangible, "thus promoting conscious awareness and deeper comprehension" (cited in Lyutaya, 2011, p.29). ER entails reading widely for pleasure, without the interruption of exercises such as daily oral reports or difficult reading comprehension questions. Therefore, a reading log should not disrupt the rules and principles of ER, but rather combined with the overall project. Although reading and writing are different skills, they supplement each other in the learning process. This fact is explained by what they have in common, including "awareness of the composition process, discourse conventions, and rhetorical elements that make up literary texts" (Lyutaya, 2011, p.29). Therefore, according to Lyutaya (2011), a reading $\log$ is an ideal method to ease access to literary texts. The various sections of a reading log activate background knowledge and introduce strategies to help students recognize the difficult features of setting, narration, plot, characters, and theme of the texts they read. Through developing their logs, learners are inspired to offer their opinions and tell their own stories; as a result, they grow more confident as readers, writers, and independent learners. Language instructors by observing clear principles and objectives of implementing ER programs have an undeniable role in guiding the learners to not only recognize how they learn, but also to actively take part in that learning.

\section{METHOD}

This study employed a quasi-experimental design using pre-test-treatment-posttest procedure to collect data with two groups. To reduce the teacher's effects, all participants of this study were selected from the classes run by the same instructor.

\section{Participants}

Thirty sophomore students, both male and female, majoring in English language and literature, studying at the department of foreign languages of Mazandaran University participated as the experimental group of this study, with their ages ranging from 19 to 21 . They were taking Reading Comprehension (II) and had already been divided into three groups of high, low, and middle achievers based on the results of the reading comprehension test of TOEFL. Twenty eight sophomore students, both male and female, majoring in English language and literature, studying at the department of foreign languages of Mazandaran University participated as the control group of this study. Their ages ranged from 19 to 22. These participants were in similar condition to the participants of the experimental group, in that they were taking Reading Comprehension
(II) and had already been divided into three groups of high, low, and middle achievers based on the results of the reading comprehension test of TOEFL.

\section{Instruments \\ Critical Thinking Test}

A critical thinking test developed by Assessment Day practice aptitudes tests was used as both pre- and posttest for both experimental groups of this study. This multiple-choice test consisted of four main sections and 86 items in general, eliciting participants' responses to certain skills of critical thinking such as making inferences, making assumptions, drawing conclusions, and analyzing the strengths of arguments. Every correct answer was assigned one positive mark with no negative mark for incorrect or unanswered replies and the total numbers were calculated out of 20 .

\section{Graded Readers}

Fifty literary graded readers in three levels of preintermediate, intermediate, and upper-intermediate were introduced to the subjects by the instructor to choose from in both groups. The subjects were also allowed to choose any other books that they were willing to read, considering the difficulty level of the books. Students were required to complete 10 abridged or 5 unabridged books during the program.

\section{Students' Reading Logs (only for the first} experimental group)

Participants of the experimental group of the study were asked to keep a reading journal for every story that they read as their extensive reading assignment, in which they would reflect their thoughts and understanding of the author's purpose as well as their own experiences regarding the themes developed. In other words, they were implicitly directed to think critically about the books they read. There was no limitation put on the way they wrote their logs, and they were encouraged to write in any way that suited their personality and style. Log writers would receive feedback on their work sheets by the instructor, given necessary hints and clues whenever necessary.

\section{Procedure}

Based on the results of the TOFEL Comprehension Reading Test grades, the participants were divided into three groups of high, low, and middle achievers in both experimental groups. All participants of the two groups went through similar approaches of intensive and extensive reading during the whole program, except for keeping logs which was given to one group only. They were required to choose from fifty literary graded readers in three levels of preintermediate, intermediate, and upper-intermediate introduced by the instructor or choose whatever literary story regarding the difficulty level of the books and their interest, as according to Day and Bamford (2004), this is one of the principles of ER that readers should choose the materials themselves. They were supposed to read extensively ten abridged literary stories or five unabridged literary works in ten sessions. Participants of the experimental group were required to keep logs for each story they read and answer the questions raised by the instructor, give their critical opinions about the characters and plot, and evaluate the theme and the writers' point of views. These journals are very similar to "instructormediated journals" in Seshachari's (1994) term. As 
Seshachari (1994) believed, unmediated journal writing does not necessarily increase "students' level of discourse, comprehension or critical thinking" ( $p$. 8). She used the term "mediation" by an instructor to refer to "teachers' motivating students through very brief pep talks and encouraging them to write critically by giving one or two examples of good critical writing examples taken from their own literary journals" ( $p$. 8). Log writers were given feedback on their log sheets by the instructor numerously during the program. Students in the control group, on the other hand, did not keep logs. They merely read extensively their selected literary stories. Posttests were held in both groups at the final days of the semester. In addition to posttests, participants' logs were collected and examined qualitatively in the experimental group.

\section{FINDINGS AND DISCUSSION}

Before analyzing the results, the KolmogorovSmirnov test was run to determine whether the dependent variable of this study was normally distributed.

HO: Asymp . sig (2- tailed) $\geq 0.05$ The dependent variable is normally distributed

H1: Asymp . sig (2- tailed) $<0.05$ The dependent variable is not normally distributed

Table 1. Normal distribution of Research Variables

\begin{tabular}{|c|c|c|}
\hline $\begin{array}{r}\text { E without Logs } \\
\text { G } \\
\text { Pretest }\end{array}$ & $\begin{array}{l}\text { E with } \\
\text { Logs G } \\
\text { Pretest }\end{array}$ & \\
\hline 30 & 28 & Number of participants \\
\hline 11.1500 & 10.5982 & Mean \\
\hline 1.67589 & 1.84760 & Standard Deviation \\
\hline .101 & .159 & $\begin{array}{r}\text { Most extreme } \\
\text { differences absolute }\end{array}$ \\
\hline 101 & 117 & $\begin{array}{r}\text { Most extreme } \\
\text { differences positive }\end{array}$ \\
\hline-.099 & -.159 & $\begin{array}{l}\text { Most extreme } \\
\text { differences negative }\end{array}$ \\
\hline .556 & .840 & K-smirnov \\
\hline 917 & .480 & P_value \\
\hline
\end{tabular}

According to Table 1, the p-value is more than 0.05; therefore, $\mathrm{HO}$ is accepted. It means that the variables of the study follow a normal distribution.

In order to answer the first research question and investigate whether literature-based ER and log writing had an effect on the critical thinking skills of the participants of the experimental with logs group, the results of the critical thinking test was analyzed through the SPSS software version 16. To determine how much progress each group had made in the interval between pre- and posttests, first descriptive statistics and then two paired samples t-tests were run. The following tables show descriptive statistics for the results of pre-test and post-test for the experimental with logs group ( $E$ with $L G$ ) and experimental without logs group (E without $L G)$.

Table 2. Descriptive statistics for (E with LG)

\begin{tabular}{llcccc}
\hline & & Mean & $\mathbf{N}$ & $\begin{array}{c}\text { Std. } \\
\text { Deviation }\end{array}$ & $\begin{array}{c}\text { Std. } \\
\text { Error } \\
\text { Mean }\end{array}$ \\
\hline Pair 1 & Pre & 11.15 & 30 & 1.67 & 0.3 \\
& Post & 10.91 & 30 & 1.32 & 0.24 \\
\hline
\end{tabular}

As Table 2 indicates, the mean score of the pretest for E with LG was 11.15 and that of posttest was 10.91 .

Table 3. Descriptive statistics for (E without LG)

\begin{tabular}{llcccc}
\hline & & Mean & $\mathbf{N}$ & $\begin{array}{c}\text { Std. } \\
\text { Deviation }\end{array}$ & $\begin{array}{c}\text { Std. } \\
\text { Error } \\
\text { Mean }\end{array}$ \\
\hline Pair 2 & Pre & 10.59 & 28 & 1.84 & 0.34 \\
& Post & 11.28 & 28 & 1.77 & 0.33 \\
\hline
\end{tabular}

As Table 3 indicates, the mean score of the pretest for E without LG was 10.59 and that of the posttest was 11.28. In order to compare the performance of the two groups to decide if logs had an effect on improving learners' critical thinking skills, an independent sample $t$-test was run, the results of which appear next.

Table 4. The Results of Independent Samples t-test

\begin{tabular}{|c|c|c|c|c|c|c|c|c|c|}
\hline & $\begin{array}{l}\text { Leven } \\
\text { for Eq } \\
\text { Vari }\end{array}$ & $\begin{array}{l}\text { Test } \\
\text { ty of } \\
\text { es }\end{array}$ & & & & st for Equali & Means & & \\
\hline & $\mathrm{F}$ & Sig. & $\mathrm{t}$ & df & $\begin{array}{c}\begin{array}{c}\text { Sig. } \\
(2- \\
\text { tailed })\end{array} \\
\end{array}$ & $\begin{array}{c}\text { Mean } \\
\text { Difference }\end{array}$ & $\begin{array}{l}\text { Std. Error } \\
\text { Difference }\end{array}$ & $\begin{array}{l}95 \% \text { Confi } \\
\text { of the }\end{array}$ & $\begin{array}{l}\text { ce Interval } \\
\text { erence }\end{array}$ \\
\hline $\begin{array}{l}\text { Equal } \\
\text { variances } \\
\text { assumed }\end{array}$ & .144 & .705 & -1.193 & 56 & .238 & -.55179 & .46268 & -1.47864 & .37507 \\
\hline $\begin{array}{l}\text { Equal } \\
\text { variances } \\
\text { not } \\
\text { assumed }\end{array}$ & & & -1.189 & 54.479 & .240 & -.55179 & .46426 & -1.48238 & .37881 \\
\hline $\begin{array}{l}\text { Equal } \\
\text { variances } \\
\text { assumed }\end{array}$ & 1.504 & .225 & .900 & 56 & .372 & .36905 & .40988 & -.45204 & 1.19014 \\
\hline $\begin{array}{l}\text { Equal } \\
\text { variances } \\
\text { not } \\
\text { assumed }\end{array}$ & & & 891 & 49.848 & .377 & .36905 & .41399 & -.46253 & 1.20063 \\
\hline
\end{tabular}

Before the examination of the results of the actual independent samples $t$-test, the results for Leven's Test for equality of variances were checked to assess whether the variances of the two groups were significantly different from each other, i.e., whether the homogeneity of variance assumption has been violated. We tested this assumption in SPSS using Leven's test for homogeneity of variances. Table 4 shows that the $p$ value for the Leven's test is greater than 0.05 , then the variances are not 
significantly different from one another (i.e. the homogeneity of variance assumption has been satisfied). It shows that the two ER and ER+ LW are homogeneous. Thus, we consider the first row of Table 5. We also used the $t$ value and degrees of freedom in the row marked "equal variances assumed". Table 5 also shows that the sig of both pre and posttests is more than 0.05 . As a result of this, there was no significant difference between the scores of two experimental groups of this study. This means both groups have done the same regarding developing critical thinking skills. Therefore, the null hypothesis was confirmed.

\section{Qualitative Evaluation of Participants' Logs}

The second research question was posed to explore the most frequently used critical thinking skill(s) in students' logs. The intention was to examine the possibility of finding certain critical thinking skills that are more likely to be found in the logs written by students who are not in the habit of reading the texts with critical eyes, and these skills are perhaps those that are emphasized in some reading comprehension books even though in an implicit manner. Learners in their logs would respond to the questions raised by the instructor and reflect on their thoughts and understanding of the author's purpose as well as their own experiences regarding the themes developed. The questions raised in the logs aimed at provoking critical responses on the part of log writers. The majority of the log writers' responses to stories were located within five major categories: 1. Personal responses, 2. Inferential responses, 3. Concluding responses, 4. Interpretive responses, and 5. Evaluative responses. Analysis of the logs was conducted by coding the entries with different codes for different responses. A "response" was defined, for the purposes of this study, as a single unit of thought written in reaction to what was read. For example, a fairly lengthy narrative relating an incident in the reader's past to an incident in the story might include several sentences or even paragraphs, but was merely computed as a single response. By contrast, a single sentence might contain more than one type of response; for example, both inferential and evaluative types. By personal responses, writers relate the themes, concepts, etc. raised in their logs to their own personal experiences, expressing their feelings and attitudes and affective reactions, usually with little elaboration or explanation (code 1). Referential responses show what writers have inferred from the clues, from those lines that do not directly but rather implicitly suggest a meaning. This shows the writers' power of inference making (code 2). Concluding responses refer to the writers' drawing conclusions, when they make a decision or a general statement considering all facts related to a situation (code 3). Interpretive responses are the responses in which writers attempt to make meaning of the lines by weighing evidence and deciding whether a generalization or conclusion can be drawn based on the given information and supporting their interpretation by moral, social and cultural conventions, and expectations (code 4). The last category, evaluative responses, are those responses that include writers' evaluating what they read, showing their agreement or disagreement by presenting reason, questioning the writers' point of view, and criticizing those ideas that are contrary to theirs (code 5).

The analysis of the logs has merely been limited to the first and last logs of 15 participants, due to the large bulk of the material. For the purpose of analyzing the logs and coding them correctly according to the above categorization, all the five categories were carefully studied prior to the actual analysis by both the instructor and researcher. Then all the logs were read and coded by them and the inter-rater reliability was estimated to be 0.98 . The following tables show the frequency of occurrence of each of the five categories from log 1 to the last log.

Table 6. Frequency of Critical Responses of Participants' First Logs

\begin{tabular}{|c|c|c|c|c|c|c|}
\hline Proficiency Level & Subjects $N=15$ & Code 1 & Code 2 & Code 3 & Code 4 & Code 5 \\
\hline $\mathrm{H}$ & $\mathrm{A}$ & 2 & - & - & 5 & - \\
\hline $\mathrm{H}$ & $B$ & 5 & 3 & - & 1 & - \\
\hline $\mathrm{H}$ & $\mathrm{C}$ & - & 2 & 2 & 2 & 1 \\
\hline $\mathrm{H}$ & D & 1 & 4 & - & - & 1 \\
\hline $\mathrm{H}$ & $E$ & 2 & 1 & 3 & 1 & 1 \\
\hline $\mathrm{L}$ & $\mathrm{F}$ & 2 & 14 & 1 & 5 & 9 \\
\hline $\mathrm{L}$ & $\mathrm{G}$ & - & 14 & 1 & 7 & 1 \\
\hline $\mathrm{L}$ & $\mathrm{H}$ & 3 & 5 & 1 & 1 & - \\
\hline $\mathrm{L}$ & 1 & - & - & 1 & 3 & - \\
\hline $\mathrm{L}$ & $\mathrm{J}$ & 4 & 3 & - & 4 & - \\
\hline $\mathrm{L}$ & $\mathrm{K}$ & 2 & 5 & - & 1 & - \\
\hline $\mathrm{M}$ & $\mathrm{L}$ & 3 & 1 & 1 & 4 & - \\
\hline $\mathrm{M}$ & $M$ & - & - & 1 & 2 & 1 \\
\hline $\mathrm{M}$ & $\mathrm{N}$ & 1 & - & 2 & 2 & 2 \\
\hline \multirow[t]{2}{*}{$\mathrm{M}$} & $\mathrm{O}$ & - & 1 & 2 & - & - \\
\hline & $\begin{array}{l}\text { Frequency } \\
\text { Percentage }\end{array}$ & $\begin{array}{c}25 \\
17 \% \\
\end{array}$ & $\begin{array}{c}53 \\
36.0 \% \\
\end{array}$ & $\begin{array}{c}15 \\
10.2 \% \\
\end{array}$ & $\begin{array}{c}38 \\
25.8 \% \\
\end{array}$ & $\begin{array}{c}16 \\
10.8 \% \\
\end{array}$ \\
\hline
\end{tabular}

In order to discover the most frequent critical thinking skill in students' writing, their reading logs specifically the first and last logs were analyzed through codes. In the beginning of the program, all the learners were in the same state of using thinking skills as their pretest-results indicated and could be considered homogeneous in this regard. This could also be seen in their first reading logs and the essay- question reports they wrote for the reading materials covered in the class. In both of these tasks, they tended to summarize the texts, repeat what had already been said in class or express their not-sorelated personal reflections on the text. This is a common problem in almost most of the reading classes, either in first or second language in our country, and somehow is indicative of the reading 
habits and the kind of reading instruction these learners have received. However, the more they got engaged in their logs and especially with the continuous feedbacks and hints of the instructor, some log writers gradually could show better thinking patterns and habits and some could make in-depth interpretation or inference. Perhaps that is why code 5 (critical responses) shows an improvement from $10.8 \%$ to $20.30 \%$ in the logs.

Table 6. Participants' Second Logs

\begin{tabular}{|c|c|c|c|c|c|c|}
\hline Proficiency Level & Subjects $N=15$ & Code 1 & Code 2 & Code 3 & Code 4 & Code 5 \\
\hline $\mathrm{H}$ & $\mathrm{A}$ & 22 & 9 & 3 & 9 & 1 \\
\hline $\mathrm{H}$ & $B$ & 16 & 1 & 5 & 5 & 1 \\
\hline $\mathrm{H}$ & $\mathrm{C}$ & - & 4 & 1 & 1 & 1 \\
\hline $\mathrm{H}$ & $\mathrm{D}$ & 4 & 4 & 2 & 2 & 1 \\
\hline $\mathrm{H}$ & $E$ & 2 & 2 & - & 2 & 4 \\
\hline $\mathrm{L}$ & $\mathrm{F}$ & - & 3 & - & 5 & 1 \\
\hline L & $\mathrm{G}$ & 2 & 20 & 1 & 4 & 2 \\
\hline $\mathrm{L}$ & $\mathrm{H}$ & 11 & 2 & 1 & 8 & 2 \\
\hline $\mathrm{L}$ & I & 5 & 4 & 1 & 10 & 8 \\
\hline $\mathrm{L}$ & $\mathrm{J}$ & - & - & 1 & 5 & 1 \\
\hline $\mathrm{L}$ & $\mathrm{K}$ & - & 6 & 1 & 4 & 2 \\
\hline $\mathrm{M}$ & $\mathrm{L}$ & 1 & - & 1 & 7 & 2 \\
\hline $\mathrm{M}$ & $M$ & 3 & 2 & 2 & - & 1 \\
\hline $\mathrm{M}$ & $\mathrm{N}$ & 4 & 1 & - & 4 & 2 \\
\hline \multirow[t]{2}{*}{$\mathrm{M}$} & $\mathrm{O}$ & 1 & 4 & 2 & 1 & 2 \\
\hline & $\begin{array}{l}\text { Frequency } \\
\text { Percentage }\end{array}$ & $\begin{array}{c}71 \\
28.17 \%\end{array}$ & $\begin{array}{c}62 \\
24.6 \%\end{array}$ & $\begin{array}{c}21 \\
8.3 \%\end{array}$ & $\begin{array}{c}67 \\
26.5 \%\end{array}$ & $\begin{array}{c}31 \\
12.30 \%\end{array}$ \\
\hline
\end{tabular}

As can be seen from the above table, code 2 (inferential responses), was the most frequently used response in the learners' first logs and code 4 (interpretive responses), was the most frequent response of the last logs, allocating $26.5 \%$ of the responses to it. Both code 2 (inferential responses) and code 3 (concluding responses) have shown an increase in frequency from 53 to 62 uses and from 15 to 21 uses respectively. The increase is not very considerable though. The reason for the dominance of code 2 in the first logs might be attributed to the presence of an emphasis on reading between the lines as a reading strategy in most of the reading books available now. In other words, students' unconscious mind was possibly focused on the closest known skill to them after summarizing the main ideas which was making inferences. But what is interesting to mention is that these inferences were not fully developed and that may be due to the fact that they have just learned to focus on making inferences when asked to do so, usually through an inferential question, and have not practiced using them in their personal responses to a text. As for the increase in code 3 , the reason may be due to the nature of the progressive feedback hints given by the instructor to the learners that directed them to draw conclusions from the stated or unstated points in the text.

An example of one of the students' logs is provided here as a sample of qualitative analysis of the content of the logs. What is interesting about this particular student's response is that she has used 8 critical responses in her last log, in contrast to her first log in which there was no use of this type of response. The following extracts show some examples of using critical responses in her last log;

".. I do not agree with Nina, fame always can't bring happiness".

".. I think the author could end this play very better. He has this power of writing".

".. I think the writer could excite the reader with different way, for his ending. Until now I 'm shocked.. just Dorn said " Treplieff shot himself" what does it mean!!? Treplieff was one of the protagonists. His life, and his way have to be said with details".

Student $\mathrm{E}$ has also shown an increase in the number of critical responses in his last log. The following extracts show some examples of using critical responses in his last log;

"When the whole thing blew over and both Troy and Boldwood were out of the picture, Gabriel did something which was both smart and foolish. $\mathrm{He}$ sends a letter to Bathsheba telling her, that he was travelling to America to work... he didn't need to do so because his luck took a different route".

"... I was really upset why the author had to omit Fanny's character from the story..".

- $\quad$ "Many may think this was the right thing to do but I think he should have expressed how much he loved her, but he didn't. This is one of Gabriel's flaws, because if you love someone you shouldn't give up with just one rejection".

Keeping logs have apparently demonstrated an increase in learners' critical thinking responses in their last logs. However, it would be rather unreasonable to claim that all log keepers made enormous gains in critical thinking abilities through writing response logs. Furthermore, since the results of the posttest did not confirm this either, it may be concluded that for certain learners, logs may be a good means of exercising their critical thinking skills but not for all. To understand why certain learners have demonstrated progress in their critical thinking skills, while others have not, more research and longitudinal studies would be required to shed more light on issues not considered in this study. One possibility that can be explored in a follow-up study would be the link between readers' critical thinking dispositions and their critical thinking ability. That is to say, those students whose mind is critically disposed would perhaps benefit more from log writing which gives them the space they need to express their reflections on the texts they read.

This study was an attempt to investigate the effect of literature-based ER plus log writing on critical 
thinking skills of sophomore EFL learners. After the logs had been coded, they were compared in an effort to determine whether changes in the numbers and types of responses from the first logs until last logs reflected any signs of critical thinking skills. Although the results of the critical thinking tests were not statistically significant, the results of the qualitative analysis of the logs were positive for all 30 logs and for all 5 codes examined by both the instructor and the researcher. The results showed improvements in the number of critical responses used in the last logs of the participants, therefore indicating more signs of thinking skills of the learners. This was in line with the studies of Barnes (1979), Clifford (1980), Browning (1986), Pezzulich (1987), Harris (1991), Reinertsen and Wells (1993), and more recent studies of Lyutaya (2011) and Aliponga (2013). All of these studies examined the relationship between reading plus log writing on the critical thinking skills of the learners. Among studies mentioned, the study carried out by Harris (1991) and the present study have much more in common in terms of the elements included in the reading logs. The logs used in Harris's (1991) study consisted of seven major categories: Affective responses, summaries, queries, associative responses, reflective responses, interpretive responses, and inferential responses, from which three categories were the same as the present study, namely affective or personal responses, interpretive responses, and inferential responses. Findings suggest that log writers did show improvements in their thinking skills in comparison to their prior logs. Findings further suggest that some students took more advantage of instructor and student feedback to make changes in their log entries and made more use of in-class discussion in arriving at ideas for writing. The logs used in the present study may have an advantage over that of Harris's (1991) in that category 5, critical responses, as the final stage of thinking abilities was much more emphasized.

Developing critical responses of the learners in the process of reading plus log writing also receives its theoretical supports from Bloom's (1956) taxonomy of educational objectives and Bakhtin's (1986) Dialogic Interpretation in Reading. Bloom's taxonomy of educational objectives in the field of education includes three highest levels of thinking (analysis, synthesis, and evaluation) that are frequently said to represent critical thinking (Kennedy et al., 1991, as cited in Lai, 2011), the very skills that were of concern in the logs used in the present study.

One possible explanation for the contradictory results obtained in the two phases of the study might be due to the difference in the means of data collection. That is to say, the first means of assessing learners' critical thinking ability was a test and the term "test" itself carries some degrees of intimidation. One possibility for obtaining non-significant result in the posttest of the experimental group might be explained by the nature of evaluating the progress; in this case, a test that is formal, long and tiring for the students in comparison to a log that is an informal, personal and friendlier space to record one's understanding and reflection on a text. Adult learning may be enhanced when students learn how to utilize and apply their critical thinking skills. Log writing provides a personal space in which thinking in a critically reflective manner assists the learning process by providing the adult learner with a tool that promotes his or her cognitive development. Students can become active participants in their learning process when they are encouraged by the logs they write to process new information in a critically reflective manner, which develops their higher-order cognitive skills (Johnson, 2013). This space that permitted learners to think and write within their comfort zone as well as the feedback they received by the instructor may have been two reasons why their critical thinking ability was clearly observable in their logs but not in their test results. This can also be explained by Bakhtin's Dialogic Interpretation in Reading.

According to Bakhtin (1986) "Any true understanding is dialogic in nature... Therefore, there is no reason for saying that meaning belongs to a word as such. In essence, meaning belongs to a word in its position between speakers; that is, meaning is realized only in the process of active, responsive understanding... Meaning is the effect of interaction between speaker and listener" (p. 102). Log writers of this study were taught that they were not to accept whatever they were presented. They learnt that meaning was recreated in an active process of reflecting, making hypotheses, rejecting or accepting the hypotheses based on the interaction between the author and the reader situated at a particular time and space. In the light of this theory, they also were numerously instructed to challenge the author's idea along with listening to heterogeneous voices of the text and responding to them.

\section{CONCLUSION}

In conclusion, due to the contradictory results obtained in the two phases of the study, the findings remain inconclusive and therefore render a new line of research which will shed more light on the issue under investigation.

\section{REFERENCES}

Al-Homoud, F., \& Schmitt, N. (2009). Extensive reading in a challenging environment: $A$ comparison of extensive and intensive reading approaches in Saudi Arabia. Language Teaching Research, 13(4), 383-401.

Aliponga, J. (2013). Reading journal: Its benefits for extensive reading. International Journal of Humanities and Social Science, 3, 73-79.

Ali, S. (1994). The reader-response approach: An alternative for teaching literature in a second language. Journal of Reading, 37(4), 288-296.

Amer, A. A. (2003). Teaching EFL/ESL literature. The Reading Matrix, 3(2), 63-73.

An introduction to the work of Stephen Krashen. 2009 .Retrieved from http://www. esl.fis.edu/teachers/support/krashen.htm.

Applebee, A. N. (1984). Writing and reasoning. Review of Educational Research, 54, 577- 596.

Ashton, P. (1988). Teaching higher-order thinking and content: An essential ingredient in teacher preparation. Gainesville, FL: University of Florida.

Assessment Day: Practice Aptitudes Tests. www.assessmentday.co.UK 
Atkinson, D. (1997). A critical approach to critical thinking in TESOL. TESOL Quarterly, 31, 71-94.

Bagherkazemi, M., \& Alemi, M. (2010). Literature in the EFL/ESL classroom: consensus and controversy. LiBRI. Linguistic and Literary Broad Research and Innovation, 1(1), 30.

Bakhtin, M. M. (1986). The problem of speech genres. In C. Emerson \& M. Holquist (Eds.), M M Bakhtin: Speech genres and other late essays (pp. 60-102) (V. W. McGee, Trans.). Austin: University of Texas Press.

Bamford, J. \& Day, R.R. 1997. ER: What is it? Why bother? The Language Teacher, 21, 6-8/12.

Barjesteh, H. \& Vaseghi, R. (2012). Critical thinking: A Reading strategy in developing English reading comprehension performance. Sheikhbahaee EFL Journal, 1(2), 21-34.

Barnes, C. P. (1979). Questioning strategies to develop critical thinking skills. Paper presented at Claremont Reading Conference annual meeting, Claremont, California, 13, 169-486.

Browning, N. F. (1986). Journal writing: One assignment does more than improve reading, writing, and thinking. Journal of Reading, 39-44.

Campbell, R. (1989). The teacher as a role model during Sustained Silent Reading (SSR). Reading, 23(3), 179-183.

Chaffee, J. (1992). Teaching critical thinking across the curriculum. New Directions for Community Colleges, 77, 25-35.

Chaffee, J. (1992). Teaching critical thinking across the curriculum. Critical Thinking: Educational Imperative, 77, 25-35.

Clifford, John. (1980). Beyond subjectivity: Transitional reading and writing. Teaching English in The Two Year College, 6, 95-100.

Davis, C. (1995). ER: An expensive extravagance? ELT Journal, 49(4), 329-336.

Day, R. (2003). Teaching critical thinking and discussion. The Language Teacher, 27(7), 2527

Day, R. R., \& Bamford, J. (2002). Top ten principles for teaching extensive reading. Reading in a Foreign Language, 14, 136-141.

Day, R., \& Bamford, J. (2004). Extensive reading activities for teaching language. New York: Cambridge University Press.

Dorn, L. \& Soffos, C. (2005). Teaching for Deep Comprehension. Portland, ME: Stenhouse.

Elliot, R. (1990). Encouraging reader-response to literature in ESL situations. ELT Journal, 44(3), 191-198.

Ellison, M. (2010). Make them think: Using literature in the primary English language classroom to develop critical thinking skills. B-F @ BULACOES, 7, 21-31.

Fahim, M., \& Bagheri, M. B. (2012). Fostering critical thinking through Socrates' questioning in Iranian Language Institutes. Journal of Language Teaching and Research, 3(6), 1122-1127.

Floris, F. D. (2005). The power of literature in EFL classrooms.k@ta,6(1),1-12.

Forood, M.S. \& Farahani, K.A.A. (2013). A comparative study between the performance of Iranian high and low critical thinkers on different types of reading comprehension questions. Theory and Practice in Language Studies, 3, 1710-1716.
Garrison, D. R. (1991). Critical thinking and adult education: A conceptual model for developing critical thinking in adult learners. International Journal of Lifelong Education, 10(4), 287 - 303.

Grabe, W. (1991). Current developments in second language reading. TESOL Quarterly 25(3), 375-396.

Ghosn, I. (2002). Four good reasons to use literature in primary school ELT. ELT Journal, 56(2), 172179.

Harris, J. (1991). Reader response logs as a learning device in literature classes. Oxford: Oxford University Press.

Huitt, W. (1998). Critical thinking: An overview. Educational Psychology Interactive. Retrieved from http://chiron.valdostaedu/whuitt/col/cogsys/critthi nk.html.

Johnson, B. (2013). Don't just teach students to think, emphasize critical thinking. Retrieved from http://www.affordablequalitywriting.com/

Kennedy, M. (1991). Policy issues in teaching education. Phi Delta Kappan, 72(9), 661-666.

Khatib, M., \& Mehrgan, K. (2012). Achieving critical thinking skills through reading short stories. Advances in Digital Multimedia, 1(3), 166-172.

Khatib, M., Rezaei, S., \& Derakhshan, (2011). A. Literature in EFL/ESL classroom. English Language Teaching, 4(1), 201-208.

Khatib, M. \& Shakouri, N. (2013). Literature stance in developing critical thinking: A pedagogical look. International Journal of Research Studies in Language Teaching, 2, 101-108.

Kubota, R. (1999). Japanese culture constructed by discourse: Implications for applied linguistics research and ELT. TESOL Quarterly, 33, 9-35.

Lai. R. E. (2011). Critical thinking: A literature review. Pearson Research http://www.pearsonassessments.com/.

Langer, J. A., \& Applebee, A. N. (1986). Writing and learning in the secondary school. National Institute of Education Grant No. NIE-G-82-0027. School of Education, Stanford University.

Lipman, M. (1988). Philosophy goes to school. Philadelphia: Temple University Press.

Paul, R. (1988). Critical thinking in the classroom. Teaching $K-8,18,49-51$.

Lyutaya, T. (2011). Reading Logs: Integrating extensive reading with writing tasks. English Teaching Forum, 1, n.p.

Nickerson, R. S. (1987). Why teach thinking? In J. B. Baron, \& R. J. Stenberg (Eds.). Teaching thinking skills: Theory and practice (pp. 27-37). New York: W. H. Freeman \& Company.

Nickerson, R. (1988-89). On improving thinking through instruction. In Review of research in education, Ernest Rothkofied, ed. Washington, D.C.: American Educational Research Association.

Nosich, G. (1992). The Goals of Science Education, in Critical thinking: Focus on science and technology (pp. 7-15). Upper Montclair, N.J.: Institute for Critical Thinking.

Norris, S. P. (1985). Synthesis of research on critical thinking. Educational Leadership, 42, 40-45.

Paul, R. W. (1993). Critical thinking: What every person needs to survive in a rapidly changing 
world. Santa Rosa, CA: Foundation for Critical Thinking.

Pezzulich, E. (1987). Reading and writing journals: Balancing skills and humanities in the English classroom. Paper presented at the Annual Meeting of the Massachusetts Council of Teachers of English Spring Conference Braintree, MA, March 26, 1987). PUB TYPE Viewpoints (120).

Pithers, R. T., \& Soden, R. (2000). Critical thinking in education: A review. Educational Research, 42(3), 237-249.

Presseisen, B. (1988). Avoiding battle at curriculum: Teaching thinking and content. Educational Leadership, 45, 7-8.

Reinertsen, P. S., \& Wells, M. C. (1993). Dialogue journals and critical thinking. Teaching
Sociology, 21, 182-186.

Seshachari, N.C. (1994). Instructor-mediated journals; Raising critical thinking and discourse levels. College Teaching, 42, 7-11.

Taglieber, L. K. (2003). Critical reading and critical thinking: The state of the art. Ilha do Desterro, 44, 141-163.

Tierney, R. J., Soter, A., O'Flahavan, J. F., \& McGinley, W. (1989). The effects of reading and writing upon thinking critically. Reading Research Quarterly, 134-173.

$\mathrm{Xu}, \mathrm{J}$. (2011). The application of critical thinking in teaching English reading. Theory and Practice in Language Studies, 1, 136-141.

Wilson, M. (1988). Critical thinking: Repackaging or revolution? Language Arts, 65, 543-551. 